\title{
A comprehensive model for assessing student teachers' professional competence through an integrated curriculum approach
}

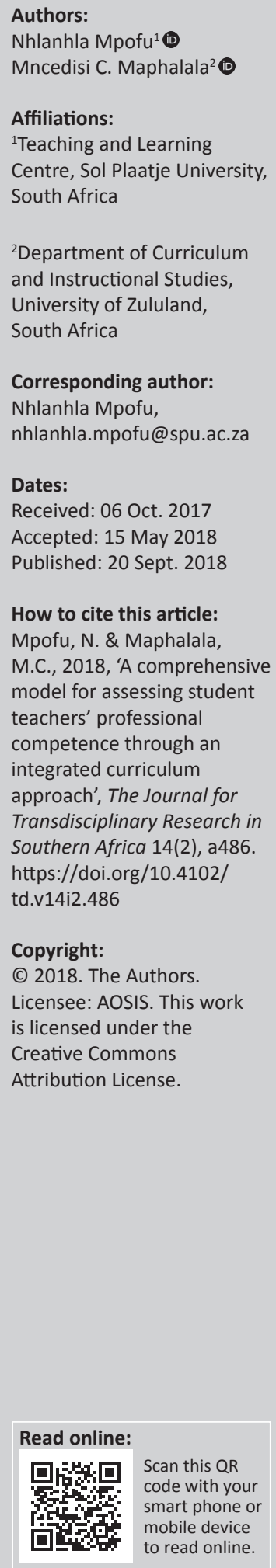

Authors:

Affiliations:

${ }^{1}$ Teaching and Learning Centre, Sol Plaatje University,

${ }^{2}$ Department of Curriculum and Instructional Studies, University of Zululand, th Africa

Corresponding author: Nhlanhla Mpofu,

Dates:

Received: 06 Oct. 2017

Accepted: 15 May 2018

How to cite this article: Mpofu, N. \& Maphalala .C., 2018, 'A comprehensive teachers' professional competence through an integrated curriculum approach', The Journal for https://doi.org/10.4102/ $14 i 2.48$

\section{(C) 2018. The Authors. Licensee: AOSIS. This work Creative Commons Attribution License.

\begin{abstract}
The purpose of this concept study was to propose a comprehensive model for assessing student teachers' competences in teaching practice. The study answered the following question: How can student teachers be holistically assessed for teaching practice using a comprehensive model? Teaching practice is a crucial component of initial teacher education (ITE) preparation programmes. However, while teaching practice is one of the most widely studied areas in ITE, international studies indicate fragmented trajectories in the assessment of teaching practice. In addition, very few studies in South Africa have reflected on how assessment is done for teaching practice during ITE programmes. In most of these programmes, performance-based, observation-based, or on-demand assessments are given preference at the expense of others. Against this background, this study was designed to produce a comprehensive model for assessment of teaching practice during initial teacher preparation from the available literature. Epistemologically, the study was underpinned by social constructivism and theoretically supported by an integrated curriculum approach. The study followed a narrative literature review approach, focusing on studies that explored ways in which teaching practice is assessed in ITE. From this analysis, the study provided a holistic and comprehensive model for assessing student teachers' professional competences during teaching practice.
\end{abstract}

\section{Introduction}

Teaching practice is a critical component of initial teacher education (ITE). According to LekeAteh, Assan and Debeila (2013:279), teaching practice is a key element of student teacher preparation and professional development. They further indicate that the other two central components are theoretical preparation consisting of various educational subjects and preparation (Leke-Ateh et al. 2013:279). Teaching practice is one of the most widely studied areas in teacher education, but very few studies have focused on how it is assessed during student teachers' formal education. This assessment is important as it is a process that uses diverse strategies to measure the students' progress, skill competence and achievement (Wei \& Pecheone 2010:69). Despite the challenges experienced when designing teaching practice assessment, most researchers acknowledge its importance as a tool for developing professional competences. In fact, referring to South African distance education student teachers, Aldridge, Fraser and Ntuli (2009) note that:

the organisation of practice teaching for teacher trainees presents both logistical and educational difficulties. Despite this, practice teaching is regarded as a pillar of teacher education as it provides opportunities for assessing both pre-service and in-service teachers in authentic environment. (p. 147)

Consequently, many researchers favour either observation-based performance, which is formative in nature, or on-demand performance, which is summative in application, for assessing teaching practice competences (Wei \& Pecheone 2010:70).

The call for quality teachers is a serious preoccupation in every country. Darling-Hammond (2010:1) argues that the public criticism of teachers has put enormous pressure on teacher education institutions to prepare their students better for the world of teaching. She maintains that any process to strengthen teacher education programmes must include a careful study of student teaching - this is a critical component as it determines a student teacher's overall ability to be an effective teacher. In South Africa, as in the rest of the world, the credibility of the assessment process used in teaching practice has been questioned with regard to its usefulness as a tool for professional development. In their study, Wei and Pecheone (2010:70) discovered that one of the difficulties inherent in this process is that it often leads to a subjective assessment, which allows incompetent student teachers to graduate into the teaching profession. 
While an assessment model for teaching practice is elusive in the literature, this is not the case with its definition. For example, Kiggundu and Nayimuli (2009) observe that in South Africa:

teaching practice is an important component of becoming a teacher. It grants student teachers experience in the actual teaching and learning environment ... During teaching practice, a student teacher is given the opportunity to try the art of teaching before actually getting into the real world of the teaching profession. (p. 345)

However, in this country, as in the rest of the world, there is no agreement in teacher education on what constitutes an effective measure of student teachers' competences resulting from field experiences. Darling-Hammond and Snyder (2000:523) note that most assessment tools are based on the belief that effective teachers possess universal traits, which include characteristics such as voice quality and a sense of humour. The authors observe that such qualities have become permanent items on student teacher assessment scales. For example, Shulman (1987:2) identifies content knowledge, pedagogical content knowledge and general pedagogical knowledge, as well as practical knowledge, as important components of the knowledge base that underlies all teachers' actions. By contrast, Maphosa, Shumba and Shumba (2007:297) note that in the Zimbabwean context, lesson planning and delivery are given prominence in assessment during teacher preparation. For their part, Darling-Hammond and Snyder (2000) mention that student teachers' competences for professional practices must be embedded in the curriculum through:

... the actual knowledge, skills, and dispositions desired of teachers as they are used in teaching and learning contexts, rather than relying on more remote proxies; assessments require the integration of multiple kinds of knowledge and skill as they are used in multiple sources of evidence which are collected over time and in diverse context ... evidence is evaluated by individuals with relevant expertise against criteria that matter for performance in the field. (p. 527)

As can be deduced from the researchers above, the strategies for assessing teaching practice are contextualised to a particular university and locale. In addition, researchers such as Ali and Khalid (2015:424) and Manzar-Abbas and Lu (2015:1) indicate that student teachers' professional practices that favour only theoretical development without experiences from the actual classroom are incomplete.

Teaching practice provides an opportunity for student teachers to put into practice the theoretical knowledge they have studied in the different courses in their programmes. Teaching practice is necessary to socialise student teachers to become effective practitioners (Ulla 2016:236). Through teaching practice, students are guided in context to understand various government and school policies, become involved in extracurricular activities, perform administrative duties pertinent to teaching (Ulla 2016:236), develop human relations with colleagues and parents, and display professionalism in various contexts (Ali \& Khalid 2015:424; Avalos 2011:10). In addition, Shulman (1987:10) states that teaching practice should expose student teachers to knowledge of educational contexts, ranging from the workings of the group or classroom, the governance and financing of school districts, and the character of communities and cultures to knowledge of educational ends, purposes and values, and their philosophical and historical grounds. For teaching practice to be effective, Trumbull and Lash (2013:2) and Marais and Meier (2004:220) argue that it should represent a range of experiences that are integrated in practice to improve the student teachers' effectiveness as a facilitator of learning.

In addition to integrating the student's theoretical knowledge into authentic experiences during teaching practice, Ali and Khalid (2015:424) and McArdle (2010:60) point to the need for effective assessment strategies to be applied. In order for student teachers to use the assessment opportunities as a learning experience, Manzar-Abbas and Lu (2015:2) note the need for the 'integration and alignment of practicum with other components' in the ITE curriculum. When assessing the students during teaching practice, their mentors should provide them with an opportunity to reflect on their strengths and weakness through what Avalos (2011:15) calls 'workplace learning or the formal and informal processes that take place and are facilitated by schools'. The feedback that student teachers receive from assessment opportunities should guide them in constructing their professional knowledge and philosophy (Ali \& Khalid 2015:424). Owing to the nature of teaching as a multifaceted phenomenon, if only one type of assessment is used its effectiveness will be limited (Le Grange \& Beets 2005:115). Accordingly, advocates of an integrated orientation to teaching practice assessment such as ManzarAbbas and Lu (2015:2), Ali and Khalid (2015:424), Çimer (2011:161), Avalos (2011:15), McArdle (2010:60), Aldridge et al. (2009:147) and Le Grange and Beets (2005:115) regard it as a pragmatic approach to developing students who are better prepared for the demands of the classroom.

Mapped against this background, this article argues that student teachers should be assessed both formatively (during student teaching) and summatively (at the conclusion of student teaching) in order to infuse the integrated curriculum they have gone through. Le Grange and Beets (2005:116) state in this regard that 'calls have been made for more authentic ways of assessing learning and for assessment to become integral to teaching and learning processes'. This symbiotic relationship is such that formative assessment serves to determine student teachers' areas of strength and weakness to inform further development and to prepare them for summative assessment. Student teachers should be exposed to the assessment criteria right from the beginning of their teaching practice, because they are critical to their success as their performance is judged on the basis of these criteria (McArdle 2010:60). This article therefore aims to provide a comprehensive model for assessing student teachers' competences during teaching practice. The article is divided into four sections: firstly, the epistemological orientation that framed the study is discussed; secondly a descriptive literature review is undertaken to examine the teaching practice assessment strategies; thirdly, the methodological approach 
that is used in the study is explicated and, finally, a discussion that highlights the proposed model for assessing teaching practice and reaffirms the significance of the study is provided.

\section{Epistemological orientation}

To account for what Ball, Thames and Phelps (2008:403) refer to as the 'natural messiness and variability of teaching and learning', we embraced a social constructivist paradigm in this study. By embracing social constructivism, we sought to explore teaching practice as an individual, collaborative and situated process that 'provides students with the necessary experience towards understanding the responsibilities of a teacher' (Ulla 2016:239). The social constructivist paradigm provided the perspective we required to understand assessment as 'active and collaborative learning rather than isolated knowledge and skills' (Sardareh \& Saad 2012:345). This holistic approach guided us in appreciating teaching practice assessment as an active process that students use to construct professional knowledge from authentic experiences enculturated in both theoretical situations (university courses) and practical situations (school-based practicum). In summary, by holding to a social constructivist orientation, we acknowledge that teaching practice assessment is a holistic process that finds meaning in social engagement. This orientation allows the students to engage in different roles to develop professional competencies.

With the epistemic worldview ensconced in social constructivism, we positioned this study in terms of the theoretical insights drawn from the integrated curriculum approach (ICA). Although the term ICA has been a topical issue in education research since the 20th century, Savas, Senemoglu and Kocabas (2012:2811) state that its definition is fiercely debated. In addition, Fraser (2011:18) states that both the definition and implementation of ICA 'remain largely misunderstood due to the number of varying definitions available and the confusion between this approach and others'. However, most studies consulted seem to align their definition to that of Beane (2016:x), who says that an ICA refers to an emphasis on the connection of a variety of study areas achieved through diminishing disciplinary focus in favour of a unified learning and teaching trajectory. On the other hand, Rheault and Von Oppell (2003:2) point out that the strength of ICA is that in its 'emphasis on real-life themes, contextual application of knowledge, and constructivist learning, the curriculum integration approach is particularly well suited to help students integrate learning experiences into their developing schemes of meaning'. From the above definitions, it would seem that the purpose of an ICA is to facilitate learning by engaging students in an authentic, meaningful and relevant scholarship that combines both theory of education and experiential practices from the field (Fraser 2011:18). The current popularity enjoyed by the ICA in higher education comes from a realisation that real world problems are not fragmented into the disciplines taught in schools but need to find meaning in the holistic learning experiences embedded in an array of academic subjects (Savas et al. 2012:2811).
The reviewed literature proposes three approaches that researchers use to underpin the study of teaching practice assessment. These approaches are multidisciplinary, interdisciplinary and transdisciplinary (Drake \& Burns 2004:ii). A multidisciplinary approach refers to a curriculum that develops connections in discipline-based themes within two or more subject areas (Rheault \& Von Oppell 2003:2). This means that a chosen theme is discussed at the same time across different disciplines. By contrast, an interdisciplinary approach '[provides] connections between subject matters ... [although the] perceived value in the unique characteristics and distinctions among the various disciplines' is maintained (Lederman \& Niess 1997:281). The third approach, a transdisciplinary approach, unlike the two approaches just discussed, does not emphasise the themes to be taught but rather the students and how they can apply theory to real-life situations (Drake \& Burns 2004:2). What this means is that student teachers do not use one specific theme or subject during teaching but draw from all available knowledge to achieve effective learning in any given context. Based on the approaches to curriculum integration discussed above, ICA may be summarised as a theoretical concept premised on contextual application and authentic and constructivist learning that instils a variety of disciplines in providing meaning to the learning experiences.

Although most studies favour one of the approaches as the theoretical foundation, the present study advocates a coherent structure that predicates teaching practice assessment as a three-part interconnected approach - that is, multidisciplinary, interdisciplinary and transdisciplinary. Such a holistic trajectory as the one we hold, seeks to underpin teaching practice assessment as 'multidisciplinary (content), interdisciplinary (skills) [and] transdisciplinary (real-life contexts)' (Rheault \& Von Oppell 2003:8). By holding to this view we sought to understand how student teachers could be holistically assessed for teaching practice using a comprehensive model. In the context of this study, we reviewed the available literature to identify assessment strategies that student teachers use and that embody the qualities of the three approaches to curriculum integration (Savas et al. 2012:2811). For this reason, we highlight strategies in the reviewed literature that integrate constructivist and traditional methods of assessment in teaching practice.

\section{Research method}

We followed a three-step process in collecting the studies we reviewed. Firstly, we gathered a list of relevant literature that focused on teaching practice assessment and an ICA using the Google Scholar, Online-Journals and EBSCOhost search engines. Using the abstracts, we retained articles that were empirical and literature based and that emphasised strategies for assessing teaching practice, an integrated approach to teaching practice assessment and an ICA in teacher education. Fifteen articles resulted from our search. In each selected article we recorded the findings in terms of the type of assessment suggested and recorded them in two columns, formative and summative. Our literature review was largely 
descriptive as we identified the suggested assessment strategies to underpin our model and answer our research question.

\section{Teaching practice assessment: A literature review}

For two reasons aligned to the purpose of our study, the literature review we carried out was narrative and largely descriptive. Firstly, the current literature on teaching practice assessment is fragmented into either formative or summative discussion with a paucity of studies that focus on an integrated approach (Trumbull \& Lash 2013:2). As this was not the focus of this article, however, we do not discuss the formative versus summative debate but describe how each type of assessment contributes to the professional development of the student teacher. Secondly, the narrative approach to the review directed our identification of the assessment strategies without individually illuminating any deficiency in the approach. This engagement was critical to our constructivist orientation as it guided us to understand each assessment strategy as discussed according to its pragmatic and experiential merits.

From the literature review, we identified the different types of assessment that are used in different ITE programmes to develop students' teaching practices. We also recognised two approaches to teaching practice, namely formative and summative performance assessments. By focusing on both formative and summative performance assessment we sought to understand how student teachers integrate:

... a variety of elements, including a vision of their teaching practice; understandings about teaching, learning, and children; dispositions about how to use this knowledge (e.g. inquiry as stance); practices that allow teachers to act on their intentions and beliefs (e.g. simulations, cooperative learning); and tools (conceptual and practical) that support their efforts and forefront the importance of considering learning in local and broader communities. (Broad \& Evans 2006:18)

\section{Formative performance assessments}

Based on constructivist notions, researchers in teaching practice advocate formative assessment (Avalos 2016:496; Sardareh \& Saad 2012:343). Formative assessment is continuously conducted to determine student teachers' progress towards socialisation into the teaching profession (Nicol \& Macfarlane-Dick 2005:106). It is aimed at helping student teachers to monitor their progress towards achieving the teaching practice learning objectives. In fact, Brown, Bull and Pendlebury (2013:4) refer to formative assessment as developmental, because it is 'concerned with improving student learning and is founded on trust between the individual and the system of assessment'. This means that formative assessment provides clear and timely feedback that helps students take charge of their learning and knowledge progression. Formative methods used for teaching practice include observation-based assessments, portfolios, self-reflection and student teachers' portfolios of evidence. Accordingly, formative assessment aligns theoretically with the notion of assessment for learning. In discussing assessment for learning, Buck, Trauth-Nare and Kaftan (2010:402) note that its potency lies largely in its ability to offer two pedagogical experiences, those of modelling and practice. Accordingly, student teachers are expected to use the feedback they receive from assessment to self-regulate their practice and reflect on effective strategies for teaching and learning (Avalos 2016:496; Sardareh \& Saad 2012:343).

\section{Reflective journals}

As an assessment tool for teaching practice, the keeping of reflection journals forms the last step in the three-part assessment for learning process. Firstly, through modelling, the student observes the experienced teacher as she or he conducts the lesson in the classroom (Kiggundu \& Nayimuli 2009:346). In this observer role, the student is tasked with assessing how an experienced teacher uses teaching and management styles in class for effective learning. Avalos (2016:502) notes that it is in this community of practice that the student and the experienced teacher develop 'a shared culture, in which teaching is reflected, interpreted and socially constructed'. In order to begin to understand their professional identity as teachers, Girvan, Conneely and Tangney (2016:130) concur that student teachers require such self-regulated and transformative opportunities as are offered by assessment for learning. Secondly, the student coteaches with the mentor teacher, gradually developing knowledge and responsibilities until the student teacher gains confidence to handle lessons alone (Diana 2014:77). This scaffolded process of learning to teach resonates with the constructivist orientation, which advocates for assessment as a developmental strategy (Sardareh \& Saad 2012:345).

To assess the knowledge that the student teacher has constructed through modelling and practice, a reflective journal is used. Writing up these journals comprises an assignment in which students are asked, according to Knapp (2012:323), to describe, compare and critically engage with aspects that they observed during a modelling or practice lesson. The inclusion of a reflective writing journal as an assessment tool has its roots in Dewey (1933:9), who states that reflection practice is an 'active, persistent and careful consideration of any belief or supposed form of knowledge in light of the grounds that support it and further conclusions to which it tends'. In addition, Schön (1983:16) defines a 'reflective practitioner' as someone who is able to consider his or her practice reflectively, not only before and after but also during the performance of that practice (reflection on action). Reflection, whether a guided or free structure, provides an opportunity for students to reconstruct, review and reanalyse their philosophy as they meaningfully observe an experienced teacher in the act of practising the profession. Knapp (2012) found in her study that through writing reflective journals, her students were able to illuminate their challenges, which ultimately improved their understanding of educational psychology concepts. Both Knapp's (2012:323) and Cohen-Sayag and Fischl's (2012:2) findings emphasise 
the use of reflective journals as a tool for self-expression and critical thinking to enhance the practice of teaching.

\section{Classroom-based observations}

Classroom-based observations also form part of assessment for learning. This type of observation, whether conducted by the mentor, the university supervisor or the student teacher him- or herself, is an important part of assessment for teaching. The New Teacher Project (2013:2) argues that classroom observations remain the most promising way to help teachers get regular, honest feedback on their teaching practice so as to improve in the classroom. Classroom observation may be conducted in such a way as to serve the purposes of both formative and summative assessments. Thus, the nature of observation depends upon its purpose. An observation conducted by the mentor teacher will be largely informal, formative and developmental in nature and will be aimed at providing the student teacher with feedback on his or her learning progress (Feiman-Nemser \& Carver 2012:342). To benefit the student teacher's development here, mentor teachers should be thoroughly oriented on how to use an observation tool (Darling-Hammond 2012:100). On the other hand, an observation conducted by the university supervisor could be formative but would generally be formal and summative in nature. When an observation is summative it seeks to assess the student teacher's overall performance; this will subsequently be presented in a formal report to determine whether the student teacher is competent or not yet competent.

Based on constructivist and integrated curriculum insights, observation should include a comprehensive assessment rubric. Such a rubric will include criteria that will enhance the experience, such that the student teachers are able to use the rubric to highlight their strengths and weaknesses with a view to improving their practice. It is therefore important to use a standardised, reliable and valid assessment tool that will provide student teachers with meaningful feedback about their development (Brown et al. 2013:4). On the other hand, some researchers indicate the importance of reflective practice in identifying the transformation in student teachers (Cohen-Sayag \& Fischl 2012:2). Therefore, a good classroom assessment tool is one that integrates both the rubrics and self-reflection practices. From the tour d'horizon ${ }^{1}$ of the rubrics for assessing teaching practice, the following themes were found to be usually measured: content knowledge; student learning; implementation of instruction; lesson preparation and planning; classroom management; learning, teaching and support materials (LTSM); and professionalism. Each of these aspects will be discussed in detail below.

Content knowledge is measured as a way of assessing whether the student teacher demonstrates mastery of the content of the subject that he or she teaches (Wei \& Pecheone 2010:70). Mastery of content alone is insufficient; the student teacher must be in a position to interpret that content and be able to share it meaningfully with the learners 1.General survey.
(Darling-Hammond 2012:180). In addition, student teachers should use relevant learning materials to make subject matter accessible to all the learners, taking into consideration their level of development, individual differences, their special needs and other factors that might have an impact on their learning.

Learner assessment is an integral part of the teaching and learning process, and therefore student teachers must be able to design and administer assessment tasks and strategies appropriate to the learning context and the area of specialisation (Wei \& Pecheone 2010:70). The student teachers must also be able to monitor learning during the teaching process to ensure that leaners are progressing towards the achievement of the learning objectives and mastering the content. We understand this to mean that the student teachers' ability to use assessment information for diagnostic and remedial purposes to promote learning is also developed. It is also essential that student teachers have the ability to provide the learners with useful feedback for their growth and development (Maphosa et al. 2007:297).

The effective implementation of instruction is also used in many rubrics to indicate the student teacher's readiness for the profession. Wei and Pecheone (2010:70) note that teaching involves the use of various teaching methods, resources and learning activities that address the learners' diverse needs to ensure that learning objectives are achieved. The student teachers' ability to communicate effectively in relaying the subject matter to the learners is important, and the teaching and learning process should be differentiated through the use of teaching strategies that cater for learners' diverse needs and abilities (Cohen-Sayag \& Fischl 2012:2; DarlingHammond \& Snyder 2000:527). This means that learners should be engaged in problem-solving that involves discovery learning and critical thinking to ensure that learning is meaningful and takes into consideration learners' contextual factors. This suggests that the content, materials, language and teaching strategies student teachers use must be appropriate for the learners' developmental level (Nicol \& MacFarlane-Dick 2005:106). We understand this to mean that through classroom-based performance observation assessments, student teachers are engaged in a developmental process meant to build their skills and competences in teaching.

A lesson plan is a roadmap that guides teachers in implementing the lesson. Student teachers therefore must be in a position to demonstrate how their lesson will pan out in the classroom and indicate the lesson aims, the content learners are to be exposed to, as well as the teaching method, learning activities, resources and assessment activities to be used to shape learning (Darling-Hammond 2012:180). According to Darling-Hammond, Newton and Wei (2013:180), the lesson plan should also indicate how the teacher will stimulate learners' interest and motivation during the teaching and learning process, as well as accommodate and support diverse learning needs. Therefore, the student teachers' lesson plan is assessed for the appropriateness of resources, 
activities, content, assessment activities and lesson objectives (Wei \& Pecheone 2010:69).

Classroom climate is one of the most important predictors of learner achievement (Thapa et al. 2013:358). No effective teaching and learning can take place in a chaotic and disruptive classroom environment. Effective classroom management involves teachers being prepared for lessons, motivating learners, providing proper and effective discipline, making learners feel comfortable, building learners' self-esteem and designing constructive and entertaining lesson plans (Williams \& Williams 2011:2). For an effective teaching and learning process to take place, the student teachers must be assessed on their ability to create and maintain a learning environment that is favourable and supportive for all learners (Wei \& Pecheone 2010:70). They should be able to apply various approaches to reinforce acceptable learner behaviour and to curtail non-compliance with the established classroom rules and procedures. This will be observable when learners follow classroom procedures and routines that support a productive learning environment for all learners. This means that in teaching practice, the student's ability to allocate teaching time effectively and maintain an environment that promotes equity, fairness and respect among the learners should be assessed (Williams \& Williams 2011:2). The learning environment has to be safe and be able to accommodate individual and group activities and the physical resources in the classroom should be placed in an orderly manner (Thapa et al. 2013:358).

Learning, teaching and support materials (LTSM) refers to any object used to convey learning content, skills and values during the teaching-learning process. These are also known as teaching aids, teaching media or teaching resources. Student teachers must therefore be assessed on their ability to incorporate learning materials to enhance the teaching and learning process. Learning materials may also include electronic devices, chemicals, print materials, physical materials, books, equipment and stationery. Research has shown that the use of LTSM stimulates learners' interest, increases the enjoyment of the lesson and in the process enriches and enhances the learning process (Stephens 2016:1). Student teachers should demonstrate that they can use appropriate instructional materials, equipment and suchlike effectively to promote student learning. In addition, they should be able to use LTSM to cater for individual learning needs. It is important that teachers serve as role models to the learners by demonstrating professionalism in everything they do; hence student teachers should display ethical and professional behaviour at all times. This can be demonstrated in various ways such as having a good attitude towards the learners, punctuality, being prepared for all lessons, treating learners with respect, maintaining the dress code as directed by the school policy and respecting the rights of others and their diversity (Wei \& Pecheone 2010:71).

\section{Student teachers' portfolio of evidence}

From the literature, it is apparent that student teachers' portfolios of evidence are also a formative assessment strategy.
As part of their practical learning, student teachers should compile a portfolio of evidence to be submitted to the university as part of both their formative and summative assessments (Darling-Hammond \& Snyder 2000:527). As an integrated assessment tool, the portfolio of evidence allows students to collect, construct and reflect on course materials that are later assessed by the lecturer against a set rubric. For example, Wei and Pecheone (2010) note that the portfolio collection can include school-based assignments, samples of lesson plans, assessment tools, self-reflective reports, artefacts, resources developed, scoring rubrics, the variety of teaching strategies used, involvement in extracurricular activities, strategies to cater for learner diversity, and parental involvement in students' learning. Weldeana and Sbhatu (2017:181) note that the collection of artefacts reflects the practicum experience and also serves as a self-assessment tool for the student teacher. The evidence in the portfolio can be communicated to the wider school community and other stakeholders to assist in decision-making and accountability, the administration of resources, extra- and co-curricular participation and human relations and can make a contribution to school development (Wei \& Pecheone 2010:71).

\section{Summative assessments}

The summative assessment provides an overall judgement of the student teachers' achievement of teaching practice objectives. It is usually formal and occurs at or near the end of a teaching practice placement, where it sums up the student teachers' performance. According to Brown et al. (2013:4), the purpose of summative assessment is to judge the performance of the student in order to promote them to the next academic level or issue them with a competence certificate. The formative element of teaching practice assessment, on the other hand, provides evidence that the student teacher is either competent or not yet competent (Nicol \& MacfarlaneDick 2005:107). Summative assessment should take into consideration the portfolio of evidence generated by the student teacher over time and the final classroom observation conducted by the university supervisor.

\section{Observation rubric}

Observation rubrics come in different sizes and shapes but they should consist of specific pre-established performance criteria to determine and describe the student teachers' performance accurately. The rubric should be short and simple. According to the New Teacher Project (2013:2), many observation rubrics are too long and complex to yield accurate ratings or useful feedback. The New Teacher Project further argues that when observers have too much to look for and think about in a short amount of time, observations start to resemble superficial checklists. Box 1 is an example of a scoring guide that could be used:

BOX 1: Example of a scoring guide.

$0=$ does not achieve assessment criteria

1 = basic achievement of assessment criteria

2 = moderate achievement of assessment criteria

3 = adequate achievement of assessment criteria

$4=$ exceptional achievement of assessment criteria 
Over and above the use of an observation rubric to rate the student teachers' performance, there should be a section in the assessment tool that provides detailed feedback to help student teachers address specific development areas.

\section{Pre-observation and post-observation conferences}

For successful and meaningful classroom observation, supervisors should hold pre-observation and postobservation conferences. The pre-observation conference is aimed at calming the nerves of the student teachers and to make sure that they are aware of what is expected of them during the observation (Ochieng'Ong'ondo \& Borg 2011:510). The discussions may also involve, among other things, the aims of the lesson, what learners should be able to know and do by the end of the lesson, the teaching strategies to be used, the assessment of learners to determine whether lesson aims have been achieved and any other concerns that the student teacher would like to bring to the attention of the supervisor or observer. Post-observation conferences are mainly meant for reflection by the student teachers on their performance and for the supervisor to provide feedback on his or her observations. The discussions should be concerned with what was achieved, what was not achieved and why; what did not go well and why; what could be done differently if the lesson were to be taught again; as well as strengths and weaknesses in general and areas for further development (Ochieng'Ong'ondo \& Borg 2011:510).

\section{Discussion: Towards a framework for a holistic assessment of teaching practice}

From the literature we reviewed we developed an integrated and comprehensive model for assessing student teachers' practice, in view of the fact that many studies do not illuminate 'a balanced and coherent assessment system - a component that has been somewhat eclipsed by the focus on assessment for accountability purposes' (Trumbull \& Lash 2013:2). Teaching is a complex activity consisting of multiple dimensions (clarity, teachers' interactions with students, organisation, enthusiasm, etc.). As such, overall ratings cannot adequately represent the integrative nature of teaching (Darling-Hammond et al. 2013:181). They may also be more susceptible to context, mood and other potential biases than are specific items that are more closely tied to actual teaching behaviours. Consequently, no single criterion of effective teaching is sufficient, and tentative interpretations of relations with validity criteria and potential biases should be assessed critically in different contexts, in relation to multiple criteria of effective teaching, theory and existing knowledge (Darling-Hammond et al. 2013:181).

Teaching practice is an important component of the process of learning to teach, as it exposes student teachers to the real teaching and learning environment in which they can practise their teaching skills in preparation for the world of teaching. In order for them to become competent teachers they need to be exposed to a range of experiences in schools during their teaching practice. However, student teachers' development must be monitored and assessed throughout the teaching practice session to ensure that they are on the right track towards becoming professional teachers. A comprehensive and credible assessment system is therefore essential to produce competent teachers (Deering 2011:67). This study has therefore proposed a model that attempts to assess student teachers' whole school experiences rather than focusing only on classroom practice. Figure 1 provides the structure of the proposed model.

Our proposed comprehensive model for teaching practice is premised on assessment as an integrated, idiosyncratic and collaborative process. As an integrated process, teaching practice will include the assessment of content, professional and policy knowledge. From the model, assessment, whether formative or summative, includes knowledge of assessing student learning; the implementation of teaching; lesson planning; classroom management; use of teaching resources; content; and self-reflection for both formative and summative purposes. According to Wei \& Pecheone (2010:71-180) and Darling-Hammond et al. (2013), the critical component in integrating knowledge during teaching practice assessment is progression. This means that student teachers should be guided by, for example reflective practices as formative assessment tools to identify gaps in their teaching knowledge. Through problem-solving, the student teachers reconstruct their orientation to teaching and learning into effective professional philosophies. The feedback from this formative assessment should be used during the summative phase of the observation to check for the development of competences. Because this process-based approach is not fragmented, the assessment is self-regulated, sustained and coherent for developing each student teacher through exposure to

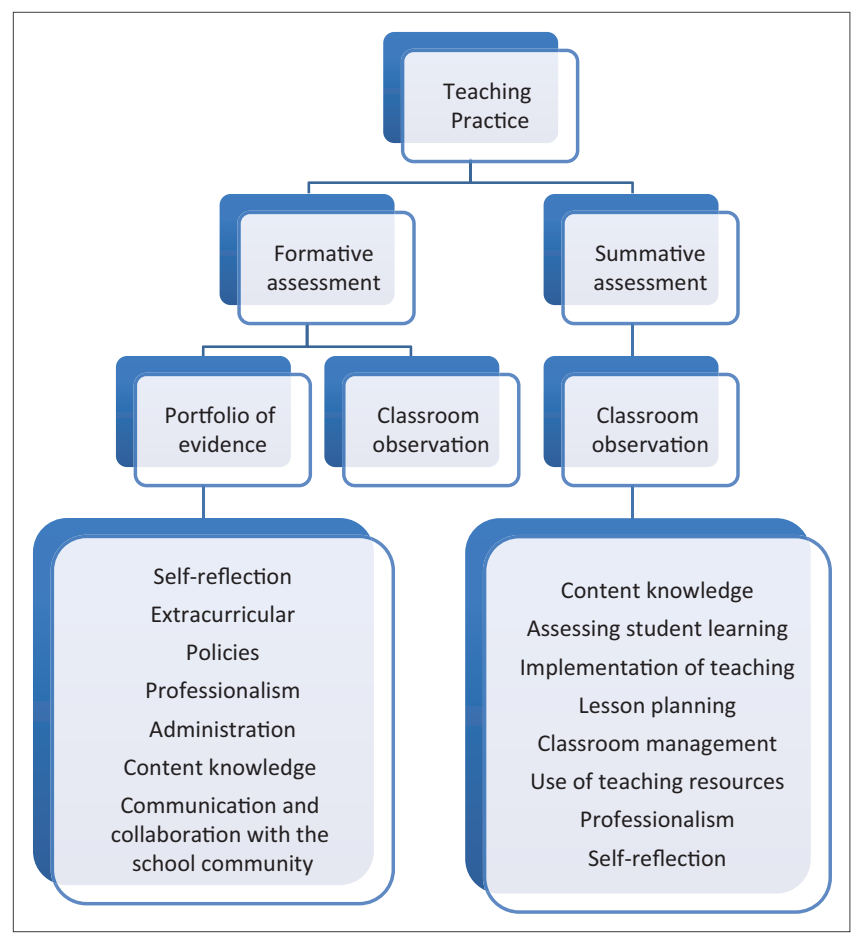

FIGURE 1: A suggested model for a holistic assessment of teaching practice. 
professional experiences. Through this model, we are making a strong case for assessment to be an idiosyncratic process.

As an idiosyncratic process, teaching practice assessment is unique, peculiar and particular. This is because, according to Darling-Hammond et al. (2009:10), 'teachers themselves judge professional development to be most valuable when it provides opportunities to do "hands-on" work that builds their knowledge of academic content and how to teach it to their students'. What this quote suggests is that rather than being viewed as evidence of deficit, teaching practice assessment should be viewed as an opportunity for active learning. From the model, we propose active learning through aspects such as class observation that include modelling and practice as tools by which student teachers receive hands-on experience. Through these hands-on opportunities, the student teachers are guided to professional noticing. Professional noticing is the awareness that student teachers hold from observing the teaching and learning environment and reflecting on what, how and why they do what they are doing (Mason 2011:36). We suggest that though modelling (Avalos 2016:497; Girvan et al. 2016:130), practice (Diana 2014:77; Feiman-Nemser \& Carver 2012:342; Knapp 2012:323) and reflection (Cohen-Sayag \& Fischl 2012:2; Knapp 2012:323), the student teachers are guided to effective teaching and learning practices. What this suggests is that assessment should offer opportunities for collaborative assessment opportunities.

A comprehensive assessment model for teaching practice is collaborative in nature. Hill et al. (2010:10) state that 'teachers develop expertise not as isolated individuals but through job-embedded professional development, and as members of collaborative, interdisciplinary teams with common goals for student learning'. Teaching practice assessment is an aspect of learning to teach that can benefit from communities of practices. By incorporating self-reflection and classroombased observation in our model, we embrace assessment opportunities that include self-reporting, peer-reporting and mentor-rating. This collaborative assessment process requires restructuring in terms of who gets to report and rate the student teacher's competence development. As teachers, we understand the reassurance that results from having assessment opportunities that require critical examination but are self-regulated and peer observed before being rated by a mentor. This is what Schön $(1983: 16)$ calls the process of reflection in action and reflection on action. The balanced assessment that results from a collaborative process is critical as a source for the student teachers' personal developmental plan for improving teaching competences (Trumbull \& Lash 2013:2).

In summary, our proposed comprehensive model for teaching practice assessment provides the student teachers with evidence for monitoring their professional competencies. The model highlights the need for feedback from others (peers and mentors) as an important assessment for and of learning in teaching practice.

\section{Acknowledgements Competing interests}

The authors declare that they have no financial or personal relationships which may have inappropriately influenced them in writing this article.

\section{Authors' contributions}

N.M. conducted data collection by reviewing existing literature on teaching practice assessment. M.C.M. conceptualised the article.

\section{References}

Aldridge, J., Fraser, B. \& Ntuli, S., 2009, 'Utilising learning environment assessments to improve teaching practices among in-service teachers undertaking a distanceeducation programme', South African Journal of Education 29(2), 147-170.

Ali, S. \& Khalid, M.I., 2015, 'Assessment of teaching practice: Perceptions of pupi teachers towards supervisors and cooperating teacher's practices', The Dialogue 10(4), 424-434.

Avalos, B., 2011, 'Teacher professional development in teaching and teacher education over ten years', Teaching and Teacher Education 27(1), 10-20. https:// doi.org/10.1016/j.tate.2010.08.007

Avalos, B., 2016. 'Learning from research on beginning teachers', in J. Loughran \& M. L. Hamiliton (eds), International handbook of teacher education, pp. 487-522, Springer, Singapore.

Ball, D., Thames, M.H. \& Phelps, G., 2008, 'Content knowledge for teaching', Journal of TeacherEducation 59(5), 389-407. https://doi.org/10.1177/0022487108324554

Beane, J.A., 2016, Curriculum integration: Designing the core of democratic education, Teachers College Press, New York.

Broad, K. \& Evans, M., 2006, A review of literature on professional development content and delivery modes for experienced teachers, Ontario Institute for Studies in Education Press, University of Toronto.

Brown, G.A., Bull, J. \& Pendlebury, M., 2013, Assessing student learning in higher education, Routledge, New York.

Buck, G.A., Trauth-Nare, A.E. \& Kaftan, J., 2010, 'Making formative assessment discernable to pre-service teachers of science', Journal of Research in Science Teaching 47(4), 402-421. https://doi.org/10.1002/tea.20344

Çimer, S.O., 2011, 'The effect of portfolios on students' learning: Student teachers' views', European Journal of Teacher Education 34(2), 161-176. https://doi.org/ views', European Journal of Teache

Cohen-Sayag, E. \& Fischl, D., 2012, 'Reflective writing in pre-service teachers' teaching: What does it promote?', Australian Journal of Teacher Education 37(10), 2-18. https://doi.org/10.14221/ajte.2012v37n10.1

Darling-Hammond, L., 2010, 'Evaluating teacher effectiveness: How teacher performance assessments can measure and improve teaching', viewed 13 February 2017, from https://eric.ed.gov/?id=ED535859

Darling-Hammond, L., 2012, Powerful teacher education: Lessons from exemplary programs, John Wiley \& Sons, Chicago, IL.

Darling-Hammond, L., Newton, S.P. \& Wei, R.C., 2013, 'Developing and assessing beginning teacher effectiveness: The potential of performance assessments' Educational Assessment, Evaluation and Accountability 25(3), 179-207. https:// doi.org/10.1007/s11092-013-9163-0

Darling-Hammond, L. \& Snyder, J., 2000, 'Authentic assessment of teaching in context', Teaching and Teacher Education 16(5), 523-545. https://doi.org/10.1016/S0742051X(00)00015-9

Darling-Hammond, L., Wei, R.C., Andree, A., Richardson, N. \& Orphanos, S., 2009 Professional learning in the learning profession, National Staff Development Council Washington, DC.

Deering, T., 2011, 'How should we evaluate student teachers?', Critical Questions in Education 2(2), 66-73.

Dewey, J., 1933, How we think: A restatement of the relation of reflective thinking to the educative process, Heath, Boston, MA.

Diana Jr, T.J., 2014, 'Co-teaching: Enhancing the student teaching experience', Kappa Delta Pi Record 50(2), 76-80. https://doi.org/10.1080/00228958.2014.900849

Drake, S.M. \& Burns, R., 2004, Meeting standards through integrated curriculum, Association for Supervision and Curriculum Development, Alexandria, VA.

Feiman-Nemser, S. \& Carver, C.L., 2012, 'Creating conditions for serious mentoring: Implications for induction policy', Yearbook of the National Society for the Study of Education 111(2), 342-364.

Fraser, D., 2011, 'Curriculum integration', viewed 17 February 2017, from http://www. nzcer.org.nz/system/files/press/abstracts/Chapter\%202.pdf

Girvan, C., Conneely, C. \& Tangney, B., 2016, 'Extending experiential learning in teacher professional development', Teaching and Teacher Education 58, 129-139. https:// doi.org/10.1016/j.tate.2016.04.009 
Hill, D., Stumbo, C., Paliokas, K., Hansen, D. \& McWalters, P., 2010, 'State policy implications of the model core teaching standards', CCSSO's Interstate Teacher Assessment and Support Consortium (InTASC), viewed 11 March 2017, from http://www.ccsso.org/Documents/2010/State_Policy_Implications_Model http://www.ccsso.org/Documents/2010/State_Policy_Imp

Kiggundu, E. \& Nayimuli, S., 2009, 'Teaching practice: A make or break phase for student teachers', South African Journal of Education 29(3), 345-358.

Knapp, N.F., 2012, 'Reflective journals: Making constructive use of the "apprenticeship of observation" in preservice teacher education', Teaching Education 23(3), 323-340. https://doi.org/10.1080/10476210.2012.686487

Le Grange, L. \& Beets, P., 2005, '(Re) conceptualizing validity in (outcomes-based) assessment', South African Journal of Education 25(2), 115-119.

Lederman, N.G. \& Niess, M.L., 1998, '5 Apples+ 4 Oranges=?', School Science and Mathematics 98(6), 281-284. https://doi.org/10.1111/j.1949-8594.1998.tb17422.x

Leke-Ateh, B.A., Assan, T.E.B \& Debeila, J., 2013, 'Teaching practice for the 21st century: Challenges and prospects for teacher education in the North-West Province, South Africa', Journal of Social Sciences 37, 279-291. https://doi.org/ Province, South Africa', Journal of
10.1080/09718923.2013.11893226

Manzar-Abbas, S. \& Lu, L., 2015, 'The practicum status in UE campuses during B.Ed. programme: TEs' perceptions', Journal of Research \& Reflections in Education programm (JRRE) 9(1), 1-16.
(JR.

Maphosa, C., Shumba, J. \& Shumba, A., 2007, 'Mentorship for students on teaching practice in Zimbabwe: Are student teachers getting a raw deal?', South African Journal of Higher Education 21(2), 296-307. https://doi.org/10.4314/sajhe. v21i2.25637

Marais, P. \& Meier, C., 2004, 'Hear our voices: Student teacher's experience during practical teaching', Africa Education Review 1, 220-233. https://doi.org/10.1080/ 18146620408566281

Mason, J., 2011, 'Noticing: Roots and branches', in M.G. Sherin, V.R. Jacobs \& R.A. Philipp (eds.), Mathematics teacher noticing: Seeing through teachers' eyes, pp. 35-50, Routledge, New York.

McArdle, F., 2010, 'Preparing quality teachers: Making learning visible', Australian Journal of Teacher Education 35(8), 60-78. https://doi.org/10.14221/ajte. 2010v35n8.5

Nicol, D. \& Macfarlane-Dick, D., 2005, 'Rethinking formative assessment in higher education: A theoretical model and seven principles of good feedback practice', Studies in Higher Education 31(2), 199-218.

Ochieng'Ong'ondo, C. \& Borg, S., 2011, 'We teach plastic lessons to please them: The influence of supervision on the practice of English language student teachers in Kenya', Language Teaching Research 15(4), 509-528. https://doi.org/10.1177/ 1362168811412881
Rheault, C. \& von Oppell, M., 2003, 'Multidisciplinary (content), interdisciplinary (skills), transdisciplinary (real life contexts) curriculum', viewed 03 February 2017, from http://www.acsa.edu.au/pages/images/rheault_von_oppell-multi disciplinary.pdf

Sardareh, S.A. \& Saad, M.R.M., 2012, 'A sociocultural perspective on assessment for learning: The case of a Malaysian primary school ESL context', Procedia-Social and Behavioral Sciences 66, 343-353. https://doi.org/10.1016/j.sbspro.2012.11.277

Savas, B., Senemoglu, N. \& Kocabas, A., 2012, 'The effects of integrated unit and constructivist based teaching learning process on fourth grades students' learning levels, attitudes towards learning, academic self-confident', Procedia-Social and Behavioural Sciences 46, 2811-2815. https://doi.org/10.1016/j.sbspro.2012. 05.569

Schön, D., 1983, The reflective practitioner, Basic Books, New York.

Shulman, L., 1987, 'Knowledge and teaching: Foundations of the new reform', Harvard Educational Review 57(1), 1-23. https://doi.org/10.17763/haer.57.1.j463w79r 56455411

Stephens, T.L., 2016, 'Encouraging positive student engagement and motivation: Tips for teachers', viewed 02 March 2017, from http://www.pearsoned.com/ education-blog/encouraging-positive-student-engagement-and-motivationMarch tips-for-teachers

Thapa, A., Cohen, J., Guffey, S. \& Higgins-D'Alessandro, A., 2013, 'A review of school climate research', Review of Educational Research 83(3), 357-385. https://doi. org/10.3102/0034654313483907

The New Teacher Project, 2013, 'Fixing classroom observations: How common core will change the way we look at teaching', viewed 02 March 2017, from http://tntp. org/assets/documents/TNTP_FixingClassroomObservations_2013.pdf

Trumbull, E. \& Lash, A., 2013, Understanding formative assessment: Insights from learning theory and measurement theory, WestEd, San Francisco, CA.

Ulla, M.B., 2016, 'Pre-service teacher training programs in the Philippines: The student teachers' practicum teaching experience', EFL Journal 1(3), 235-250. https://doi.org/10.21462/eflj.v1i3.23

Wei, R.C. \& Pecheone, L.R., 2010, 'Assessment for learning in preservice teacher education: Performance-based assessments', in M.M. Kennedy (ed.), Teacher assessment and the quest for teacher quality: A Handbook, pp. 69-132, Jossey Bass, San Francisco, CA

Weldeana, H.N. \& Sbhatu, D.B., 2017, 'Portfolio of evidence: An assessment tool in promoting geometry achievement among teacher education college students', Eurasia Journal of Mathematics, Science and Technology Education 13(6), 1981-2004. https://doi.org/10.12973/eurasia.2017.01210a

Williams, K.C. \& Williams, C.C., 2011, 'Five key ingredients for improving student motivation', Research in Higher Education Journal 12, 1-18. 